\title{
The Impact of Peer Learning within a Group of International Post-graduate Students - A Pilot Study
}

\author{
By Swapna Williamson* \\ Laila Paulsen - Becejac
}

Peer learning has been used as a teaching tool with both undergraduate and postgraduate students since the early 80s. This approach is useful when working with international students to develop their independence as learners and to share their knowledge with their peers. The aim of this paper is to examine whether peer learning is effective in active and shared learning in small groups, so as to enhance the students' overall development as a post graduate research student. Initially the students were briefed as to the purpose of this study. The instructional approach used to help students to become actively engaged in their own learning process involved in the formation of self-selected learning sets. Within these groups, the students explored the concepts covered in their lectures and presented in their findings to the class. Part of this process involved peer and tutor feedback, as well as self and peer assessment on the performance of the group members. The students additionally completed a pre and post SRSSDL questionnaire. Attendance to lectures was varied, not least affected by external events in the students' home countries at the time of this study. This impacted the amount of data collected in this pilot study. However, the initial results indicated that this teaching and learning approach was beneficial to the students. The key findings indicated that the students used peer learning in the classroom successfully in achieving the module learning outcomes. The overall performance of these students in the module was good and it has impacted their overall academic performance.

Keywords: collaborative learning, peer assessment peer learning, reflective learning, SRSSDL

\section{Introduction}

International students constitute a considerable number of the student population in Higher Education Institutions (HEIs). The effectiveness of peer learning has been found to be suitable in undergraduate international students as they go through the transition phase, where they need to make various adjustments through interactions with their peers (Zacchagnini \& Verenikina, 2013; Chilvers, 2014). Chilvers (2014) states that for post-graduate international students experience similar challenges, whilst making the transition into Higher Education Institutions abroad. Peer learning has been in use as a teaching tool since 1981 (Topping, 2005). At that time, the main focus was on primary

\footnotetext{
* Associate Professor, University of West London, UK.

${ }^{\dagger}$ Senior Lecturer, University of West London, UK.
} 
learning and peer assessment. It has since evolved into something which requires the student to actively participate in obtaining and sharing information amongst peers (Boud \& Lee, 2005). HEI's are currently promoting the importance of employability skills, and through peer learning students develop transferable skills valued by employers e.g., communication skills, social skills, organisational skills, attitudinal or interactive gains and being an evaluator (Topping, 2005; Johnston, 2009). Therefore, the notion of using the peer learning approach with international students was to address their diverse but unique needs in the context of higher education.

Peer learning is an educational process where students interact with their peers who share an interest in the subject and learn both with and from each other (Boud, Cohen, \& Sampson 2001). Thus this learning approach is beneficial for students in their quest for knowledge, ideas and experiences shared within the classroom. This in turn enables them to develop their dependence, which leads them to become more interdependent and yet independent in their ability to share with and learn from each other. According to Keenan (2014) HEIs, both nationally and internationally, greatly emphasise the use of instructional strategies that require students to be more actively engaged in their own learning process. Strategies such as Problem-Based Learning, where peers actively learn from each other further enhancing the development of critical thinking skills amongst students (Stone, Cooper, \& Cant, 2013). Moreover, due to the unprecedented increase in the number of students from diverse backgrounds, especially international students with differing abilities, peer learning has been shown to be cost-effective in catering for students without affecting the standards and quality of learning experiences offered by educational institutions (Keenan, 2014). Additionally, the advancement in information technology within the educational setting necessitates a shift in the educational paradigm from a teacher-centred to a learner-centred instructional approach (Dearnley, McClelland, \& Irving, 2013).

Peer learning can be both teacher and student led. This focuses on teaching and learning strategies involving groups of students actively involved in maximising their learning in small groups (Gwee, 2003; Johnston, 2009). Tutors need to structure the process and facilitate student learning activities so that students can fully benefit from the opportunity of interacting with their peers. This paper illustrates the impact of peer learning, the introduction and evaluation of a structured peer learning approach in the teaching of research methods to a group of level 7 international students and their overall evaluation of the learning experience. The method used was to compare the outcome of the peer learning with their academic performance.

\section{Background}

Peer learning emphasises learning with and from each other (Boud, Cohen, \& Sampson, 2001). It is a collaborative learning strategy that involves students working in pairs or in small groups enabling them to discuss concepts 
and find solutions to issues/problems. The essence of peer learning is to help students to learn from each other, to actively participate, to be innovative and to take responsibility for their own learning. It also provides students with the opportunity to explore, collect, analyse, evaluate, integrate and apply relevant information for completing learning tasks or solving problems. This approach enables students to develop interpersonal communication, team work, project management, research, and study skills (Boud, Cohen, \& Sampson, 2001).

Planned peer learning involves a group of students selected by either students themselves or by the teacher to work together to identify their own learning needs and planning strategies to achieve them. This may help students develop the communication and collaborative skills necessary for effective and efficient team working. Stone Cooper and Cant (2013) maintain that students working in small groups are better able to focus on orchestrating their own learning activities than by traditional teaching methods, taking more responsibility for their own learning and helping them to learn how to learn. According to Landis (2000), students working in small collaborative groups become more active in their learning because they improve their academic performance obtaining a better learning experience and enhancing their selfesteem. Additionally, they learn the value of student-student interaction resulting in the development of interpersonal skills, teamwork skills, critical thinking and problem-solving skills (Brookfield, 1987). Thus, according to this research, effective peer learning enables students to develop valuable transferable social and communication skills i.e., listening, explaining, questioning, summarising, speculating, and hypothesising (Topping 2005). Shipman and Hootan (2008) support the benefit of varied and interactive teaching methods adopted in the peer learning approach, as it helps to address the diverse needs of the ever increasing student numbers in the educational institutions.

Vygotsky (1978) states the importance of social interaction in learning. He went on to link the theory of social constructivism, which places an emphasis on the role of social interaction in peer learning. Peer learning encourages interaction, reflection and students' involvement in critical analysis through self-and peer-assessment as they work through a series of "scaffolded" learning activities that in turn help them to move through the stages of peer learning. Vygotsky (1978) further emphasises that the students' opportunity to extend their knowledge, understanding and their capacity to learn as they collaborate in the learning environment is integral to peer learning.

The reciprocal nature of peer learning is beneficial for students to learn from each other in developing coaching, team leadership and management skills, reflective and self-directed learning skills (Boud \& Lee 2005; Stone, Cooper, \& Cant, 2013). Educators have the responsibility of developing the students' full potential through the use of effective self-directed learning, thereby building and maintaining a harmonious team relationship in the classroom. Through the implementation of peer learning, students in small groups assume their own roles in learning by independently exploring information. They monitor their own learning progress identifying their strengths 
and weaknesses, making a conscious effort towards self-improvement, which is the prerequisite for self-directed life-long learning for effective personal and professional development (Williamson, 2007).

The potential benefits of peer learning have been recognised (Boud, Cohen, \& Sampson, 2001). Small group activities aid students in developing a variety of skills such as working collaboratively with others, taking responsibility for their own learning and sharing information. The interaction between peers helps students gain a deeper understanding of the topic, of giving and receiving feedback and of evaluating their own learning.

International students bring with them a unique set of challenges, as they seek to pursue their studies abroad. These include loneliness, emotional adjustments, social isolation, language barriers/difficulties and culture shock. They also have to adjust to a different educational system with the attached requirements. For these students it is imperative they have a structured system of support, both as a group, and individually. That support will need to address their emotional, social and academic needs (Zhao \& Kuh, 2004; Lenning \& Ebbers, 1999). This in turn will help them to be better adjusted to the demands of the course, engagement in learning, retention and overall satisfaction (Zhao \& Kuh, 2004; Tinto, Russo, \& Kadel, 1994).

\section{Methodology}

Following the module evaluation from previous groups, the module team proposed a revised teaching and learning approach for the delivery of this module. The module leader had previously developed the Self- Rating Scale of the Self-Directed Learning (SRSSDL) tool (see Appendix 1) for students to evaluate their own learning skills. Based on their learning skills students can then plan how they further develop their skill set through the use of identified strategies.

Following a review of the literature on peer learning the module team decided that the SRSSDL tool was to be used as part of the pilot project. The SRSSDL tool would be self-administered to assess the students' learning skills prior to the introduction of peer learning. It would again be completed at the end of the module to establish whether peer learning had impacted on their overall learning and academic performance within the module.

The aim of this paper is to examine whether structured peer learning is effective in active and shared learning in small groups enabling students to develop in-depth knowledge and an understanding of research methods so as to enhance the students' overall development as post graduate research students. The students on this module were enrolled on a Master Programme for international students.

To this end, the team set out to identify the learning needs through the completion of the SRSSDL form before and after undertaking this exercise. The students worked as part of a peer learning group to facilitate their own learning, thereby developing the ability to give each other constructive peer 
feedback. This enabled them to become more reflective independent learners in terms of developing their learning skills. These skills are then transferable to other learning experiences, whether in the classroom setting or as part of their self-directed learning.

Of the 66 students initially enrolled on the module, 40 attended the module sessions consistently and therefore were able to take advantage of the peer learning activities. On the first day of the module, there was a lead lecture on peer learning and the process was discussed with them. They were made aware that this activity in the classroom would be evaluated throughout the module and they gave verbal consent for this to take place.

The students self-selected five people within their class to form a peer learning group. They were expected to work together as a group for 2-3 hours per week, either face to face or online and provide one another with feedback on the identified structured learning task. Each week the students had a lead lecture on research methods e.g. quantitative/qualitative/mixed methods of research. The following week, in their peer learning groups, the students were then expected to give a short presentation to highlight their understanding and further exploration of the topic. After each presentation, the students were required to complete the peer learning assessment/self-assessment tool (see Appendix 2).

Within each learning group, there were five identified roles - that of the team leader, note taker, presenter, monitor and evaluator. These five roles were identified following a literature review of peer learning. The format and wording of the peer learning assessment/self-assessment tool was initially content validated by a team of academic staff in the field of teaching and learning. The students were given detailed written information about peer learning, the expectations of each role and the scoring to be used with the peer learning assessment/ self-assessment tool. Within the rubric, there were eight criteria against which each team member would be scored, earning a score of very good, good, satisfactory or not satisfactory. When the tool was initially developed, the module team deliberately did not give students five options for scoring in order to encourage students to carefully consider each criterion in terms of a specific role.

The students rotated through each of these five roles at least once during the course of the module. After the presentation each week, each group member scored all their group members according to the 8 identified criteria (refer to Appendix 2). The tutors also gave the individual groups constructive verbal feedback and the discussion was also opened up to the wider group for a more general discussion. This gave added richness to the student's experiences in the module. The tutors summarised the overall marks by group, week number and role (see Appendix 3).

At the end of the module, the students were asked to evaluate the overall process of peer learning used to deliver the module. This was done both through the University module evaluation processes and by completing the SRSSDL tool individually. The difference between the pre and post test scores would be compared to establish any links to the peer learning process. 


\section{Results}

All the students completed the SRSSDL questionnaire as a pre-test and many of them also completed it as a post-test (see Figure 1).

Figure 1. SRSSDL Scores - Pre and Post Peer Learning Activities

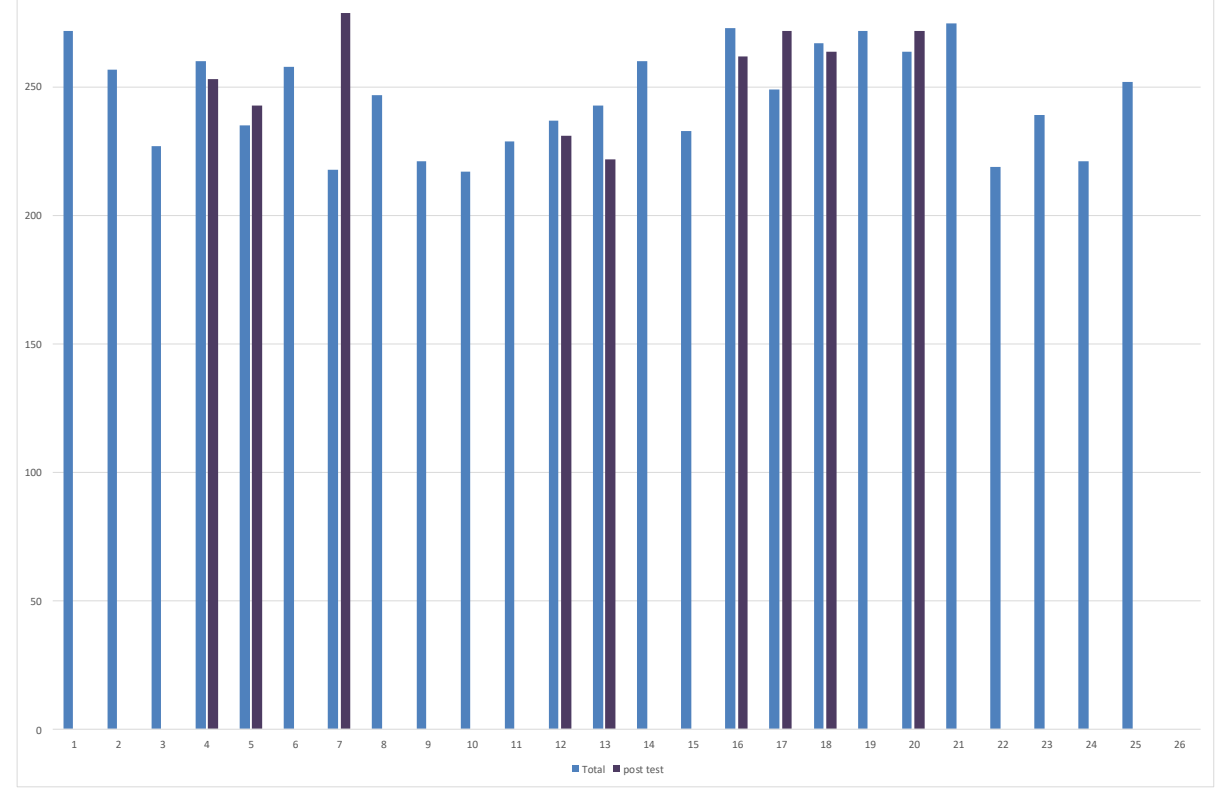

The attendance in class varied greatly from week to week and there was some confusion in the beginning as to who was actually enrolled on the module. This meant that we started with two groups giving feedback and participating in the peer review process in week three (see Figure 2), to 8 groups in week 3 (see Figure 3). By the end of the module there had been 12 groups formed although the groups formed later did not attend all of the remaining sessions. Their overall attendance was affected by the fact that a few weeks into the module there was large earthquake in Nepal. The majority of these students was either from Nepal or neighbouring countries, and was obviously worried about their relatives' safety. Consequently, the peer learning process was interrupted and this made it more difficult to measure the impact of this learning approach in the classroom. 
Figure 2. Peer Learning Assessment Scores from the 2 Groups that Started on Day 1 of the Module and Gave their First Presentation During Week 2 (Using the Peer Assessment Tool in Appendix 3).

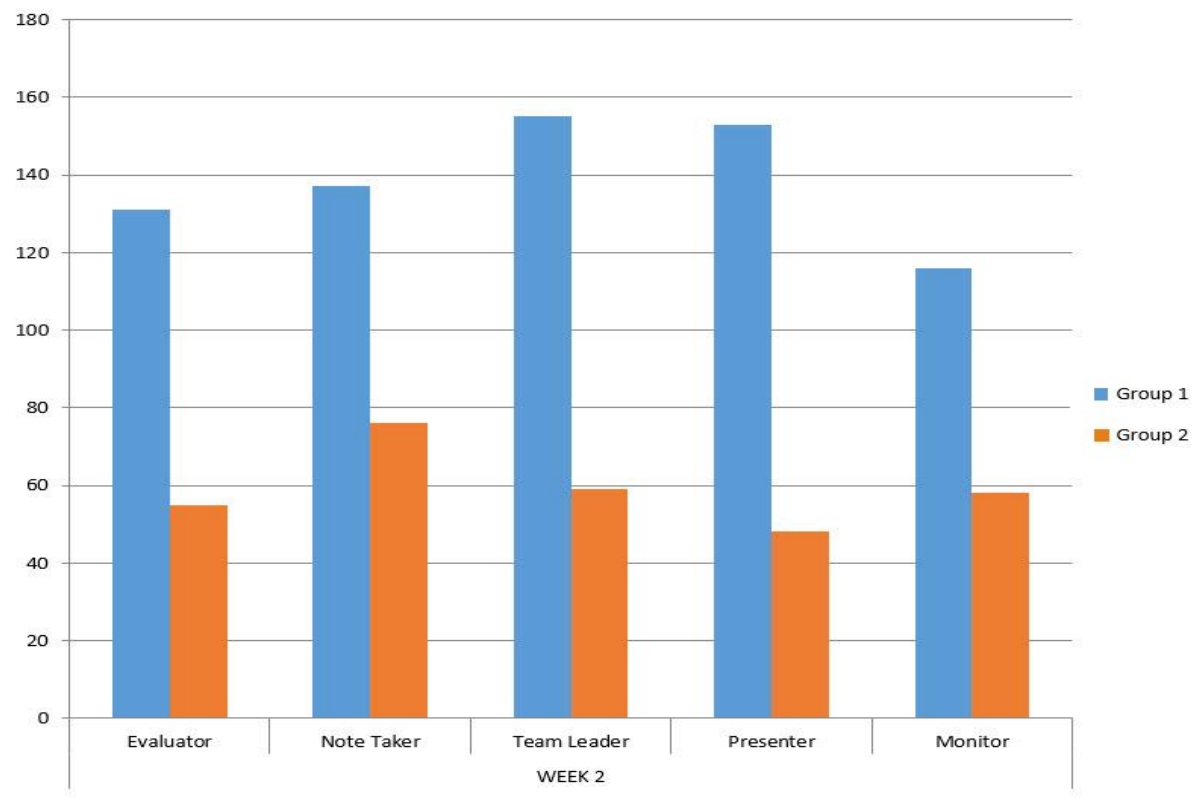

Figure 3. Peer Learning Assessment Scores from 8 Groups, Presenting during Week 3 of the Module (see Appendix 3 for the Tool Used)

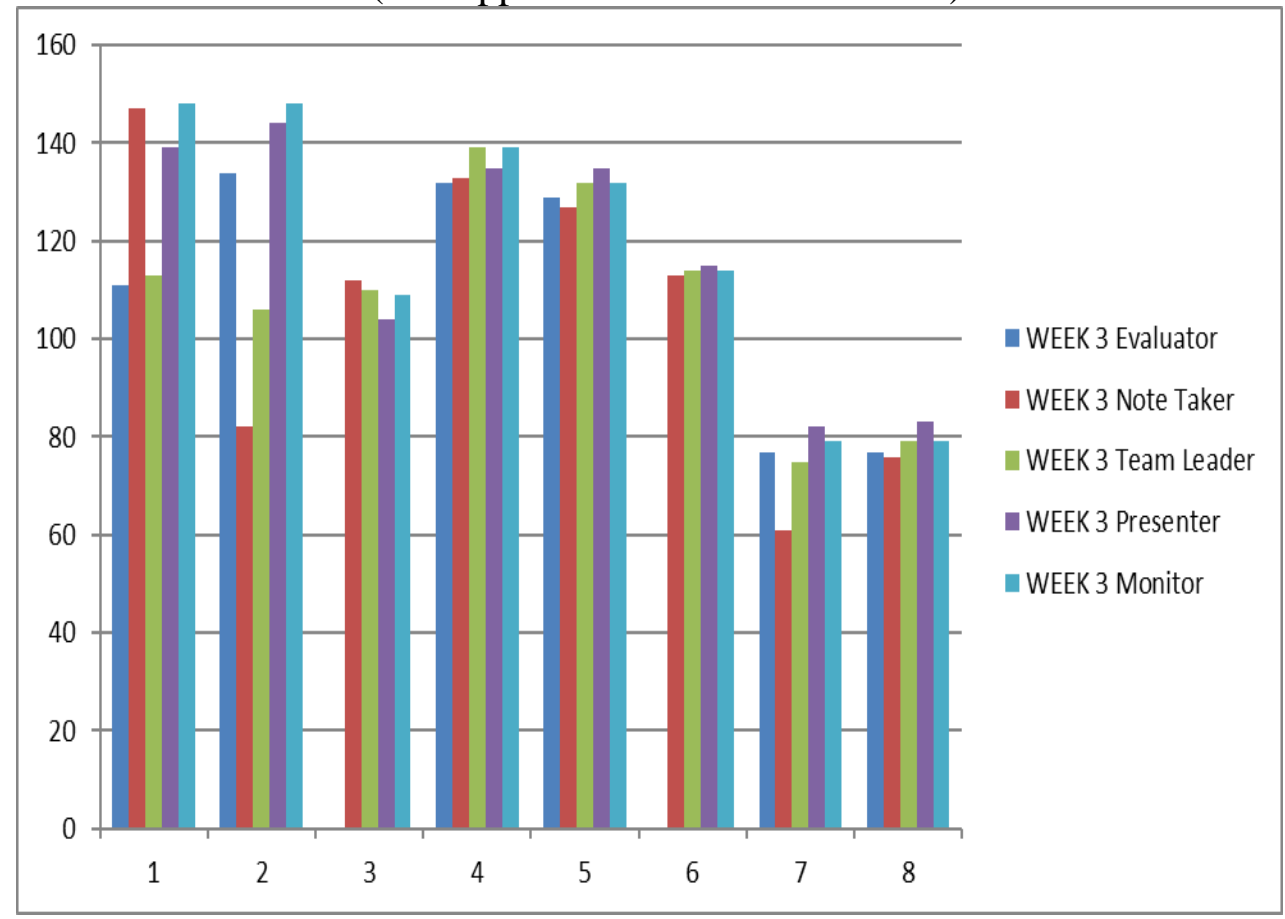

Figure 4 reveals the results from all the groups across all the weeks of the module. For each role, students could score each other from $1-4,4$ being very good and 1 being unsatisfactory (see Appendix 2). The roles of the evaluator, 
the presenter and the team leader tended to be scored consistently higher. As peer learning aims to teach the participants a range of skills, not just the content, this would appear to reflect the areas that the students felt were more significant. Figure 4 clearly shows the changes in attendance during the module.

Figure 4. Peer Learning Assessment Scores across the Module (see Appendix 3 for the Tool).

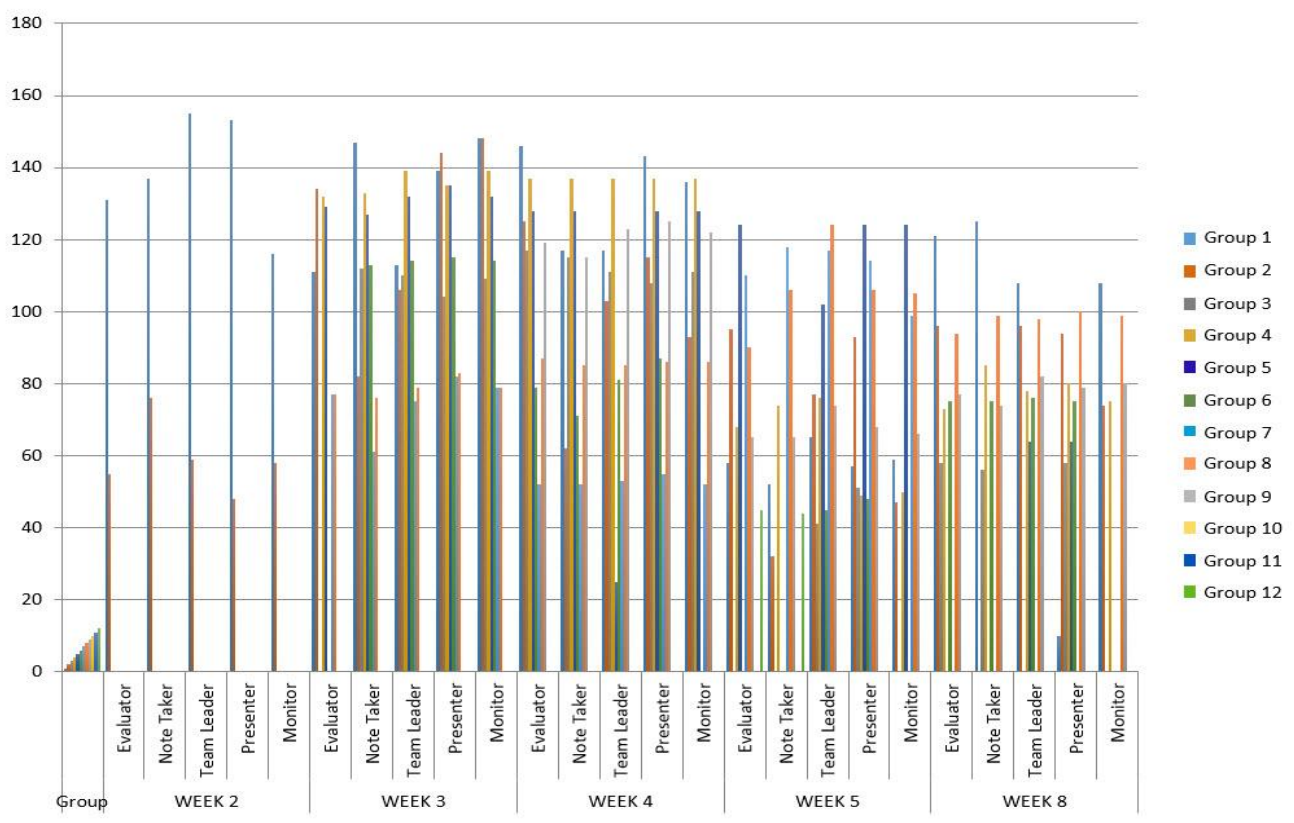

The team also looked at the overall results for their assignment to see if undertaking this process in class had an impact on their achievements. 54 students were due to submit. Marks at the first attempt ranged from $25-74 \%$, with 19 students earning a mark of $60 \%$ or more. 16 students achieved a borderline pass in the 50s. 13 students needed to resubmit their assignments and all passed at the second attempt. 4 students did not submit at either an attempt therefore failing the module. 
Figure 5. Students' Module Marks at First and Second Attempt

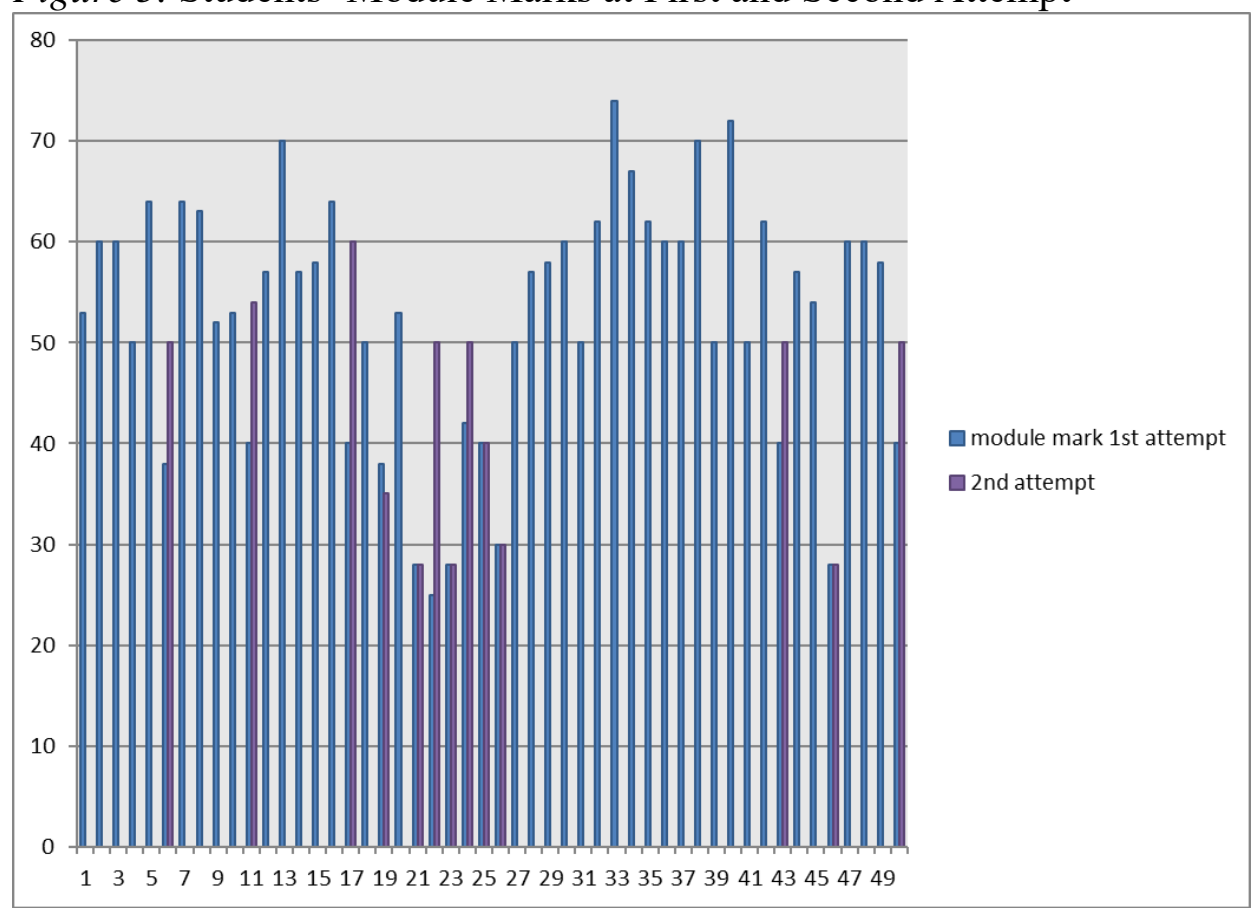

\section{Analysis}

\section{SRSSDL Scores}

All the students completed a pre and post-test using the SRSSDL tool. Only a few students undertook both the pre and the post test. Therefore this would need to be repeated with another group to see if there is a real impact on self-directed learning when using the peer learning approach in the classroom.

For those who undertook the pre and post-test, some showed an improvement. This could be due to the fact that they may have been more honest in their initial assessment of their own ability. The team also found that many students made mistakes when collating their own scores on the pre-test. Their perception of their own ability may have been inflated, resulting in a "falsely high" score.

Others showed a slight decrease in their score, although it did still remain in the high band of the scoring. Again, this could be attributed to their own perception of the level of their study skills. It may be that these students being enrolled on a Masters course felt that they should be "higher" than they actually were.

There was no drop in the score from a high to a moderate field in the pre and post test scores reflecting the students' abilities to be self-directed throughout the delivery of the module. These students made the most of the opportunity afforded to them in the classroom to take charge of their learning and they clearly benefited from this process. 


\section{Self-assessment of Roles}

There was some initial confusion amongst the students as to what their roles should be and what the purpose of the peer learning activity was. This was explained several times by the module team. The students clearly identified who was taking on which role for their presentation the following week. Figure 4 shows that their group learning was seen by the participants to be of value.

The participation declined slowly as the module progressed. This may have been in part due to the circumstances abroad as many of the students had been directly affected by the earthquake in Nepal. This did not stop the learning process but it had a negative impact on the overall process. Although there were absentees from within the groups the remaining members covered the roles of the missing people in order to take their learning forward. The missing member continued to participate in the peer learning activities outside of the classroom. Taking responsibility in this way has demonstrated that the students have taken ownership of the peer learning process from within the group.

\section{Module Marks}

Marks at the first attempt ranged from $25-74 \%$, with 19 students earning a mark of $60 \%$ or more. 16 students achieved a borderline pass in the 50s. Only 13 students submitted to a second attempt. Of these 13 students, 7 improved their mark significantly. 6 students failed at the second attempt. 4 students had not regularly attended class or participated in the peer learning process - these students did not submit their assignments.

Following the conclusion of this study, two students, who due to personal issues did not pass the module, subsequently repeated the module. It was very clear that these two students had learned from and continued to follow the principles of peer learning with their new classmates. These new students were asking questions about the peer learning process and indicated that they would have liked to have had the opportunity to participate in this process as well.

\section{Discussion}

Learning is an individual process which needs to be facilitated. Helping students to learn is our focus as tutors. Historically students on this research methods module had struggled in grasping some of the basic concepts and fully understanding the research process. The module team wished to explore alternative methods to encourage students and help them gain a better understanding and mastery of the research methods. In addition to this, these students have also developed their critical thinking skills and have gained the confidence to become independent self-directed learners (Zaccaganini \& Verenikina, 2013). 
The inclusion of peer learning within the module activities sought to develop other learning skills amongst these students. These learning skills, e.g. leadership, communication and literature searching skills, all underpinned the overall learning experience. It was recognised that for some students the lack of prior knowledge and understanding of the research process became a hindrance to their learning. By giving the adult learner more responsibility for their own learning, with guidance, students should be able to manage their own learning (Gwee, 2003). They gained transferrable skills relating to time management, group dynamics, social skills, networking and questioning techniques to enable them to achieve a deeper level of thinking and therefore learning (Keup, Rogan, \& Kenedy, 2015).

The SRSSDL tool (Williamson, 2007) was used to give students a structured approach by which they could self-assess their own ability and help them identify where they are in their learning processes and to focus on any deficits in their learning skills (Cadorin, Suter, Saiani, Williamson \& Palese, 2010). This tool has been revalidated in different settings and contexts reinforcing its applicability to all students including the international student body. It has consistently been found to be a useful tool in the further development of learning skills (Cadorin, Suter, Saiani, Williamson, \& Palese, 2010). This has also resulted in an improvement in their ability to think critically and an improvement in their peer working and team working skills (Gwee, 2003), thereby enabling them to become independent self-directed learners. These students are adult learners and they need to take ownership of their learning (Gwee, 2003). Knowles (1975) and Hiemstra and Brockett (1984) also advocated a proactive approach to learning where the student needs to take the initiative to self-manage their own learning process. Knowles (1980) goes on to say that students entering into educational programmes without the ability to be self-directed learners tend to experience more anxiety and frustration.

When completing the SRSSDL tool the quality of their responses varied in that some considered what the scale meant in more detail than others. It was unclear if they fully comprehended what was being asked of them in the questions which could in part be due to their grasp of English and their familiarity with the use of tools of this nature (Zaccagnini \& Verrenikina, 2013). Although they may have been taught in English before, the way in which teaching in English is conducted in another country has the potential to be very different, and could be to the detriment of the international students when they first start their course of study in the UK (Chilvers, 2014). Their lack of subject specific knowledge at the start of the module was compounded by the communication barriers potentially created when they moved to study in the UK. This in turn could therefore impact on the pre and post SRSSDL scores. It was more significant in the findings that these pre and post SRSSDL scores did not drop from one band to another but that they stayed in the same band.

Piaget (1972), in his theory of cognitive development emphasised the importance of students' interaction with the world and the importance of 
teachers' in assessing a child's readiness for learning. This theory has been supplanted in part by the social constructivist theory of learning (Vygotsky, 1978), which identifies the teachers ability to scaffold pupils learning beyond their current stage of understanding. Vygotsky also stresses that knowledge is constructed through the interaction with others.

Attendance was very irregular. Students started attending the module on different weeks, so having started with two learning groups, this increased to 12 learning groups by the end of the module. Some of the students came from Nepal and the module was delivered during the time of the earthquake in Nepal which meant that they might have lost focus. A number of students did not attend the first session of the module where the learning sets concept was introduced by the module team. All students were given a written brief description on what the expectations were. However those joining the module later tended to ask their classmates for clarification which resulted in shared learning (Boud, Cohen, \& Sampson, 2001; Gwee, 2003).

Initially, the students tended to repeat the information from the previous weeks lecture rather than trying to apply their learning. The feedback from the peers and well as the teachers forced the learning sets to re-evaluate their brief and to work more collaboratively as a team. Their roles changed during the course of the module from one of a passive learner to that of independent selfdirected learners (Gwee, 2003). These findings are similar to the results reported by Zaccagnini \& Verenikina (2013), who found that the overall experience was a positive one for the students and they requested more opportunities to learn in this way.

The students tended to stay in groups of people from similar cultural backgrounds - this may have affected their socialisation while studying in the UK. Zaccagnini and Verenikina (2013) suggested that international students felt that staying with classmates from a similar background allowed them to advance their learning, especially in terms of jargon or terminology that might be unfamiliar to them. International students encounter some unique challenges including the transition to higher education in the UK (Chilvers, 2014). However peer learning can be seen as an example of an effective approach for supporting students in their academic, social and emotional adjustments (Zhao \& Kuh, 2004). The findings from this small scale study would appear to support this, in that some roles were seen as being more important in the peer learning process. This in turn demonstrated that they were actively participating and negotiating in their learning process taking ownership of their overall experience. As part of this experience students have taken on different leadership and monitoring roles, which further developed their ability to function independently and to become more self-reflective in their ability to give each other constructive feedback (Gwee, 2003; Gielen, Peeters, Duchy, Onghema, \& Struyven, 2010)

Anecdotal information would seem to indicate that the students performed better in this module but that would need to be verified through repeating this process with subsequent groups. The researchers were pleased to see that there were no academic failures in this module - the four students who failed had not 
submitted their assignments. This would seem to indicate that if students are given the appropriate support and challenges during their studies they will rise to it. They successfully complete the tasks set for them, achieve the learning outcomes and pass. This further reinforces the importance of good communication skills as part of the peer learning approach (Gwee, 2003). Following the conclusion of this study two students who failed to submit due to personal circumstances are now retaking the module. It has been observed and commented upon that these students clearly developed skills from the peer learning approach that has had an impact and they both achieved high marks for their current work.

\section{Conclusion}

The pilot study sought to explore and evaluate the value of peer learning with international students undertaking a post graduate research methods module. The aim was to develop a sound knowledge base on research methodologies as well as developing the students learning skills which are transferrable and applicable to any learning environment.

The key findings were that the students benefitted from the use of peer learning and were successful in achieving the learning outcomes. As the circumstances at the time had a potential impact on the performance of these students, the study will need to be repeated with the subsequent groups. Another aim would be to see if there is a real impact on self-directed learning when using the peer learning approach in the classroom. Despite these hurdles the overall performance was good. The effectiveness of the social learning theory has been recognised within the results of the students overall performance.

\section{References}

Boud, D., Cohen, R., \& Sampson, J. (Ed.) (2001). Peer learning in higher education: learning from and with each other. London: Kogan Page Ltd.

Boud, D., \& Lee, A. (2005). 'Peer learning' as pedagogic discourse for research education. Studies in Higher Education, 30(5), 501-516.

Brookfield, S.D., (1987). Developing critical thinkers. San Franciso: Jossey-Bass.

Cadorin, L., Suter, N., Saiani, L., Williamson, S.N., \& Palese, A. (2010). Self-rating scale of self-directed learning (SRSSDL): preliminary results from the Italian validation process. Journal of Research in Nursing, 1(11).

Chilvers, L. (2014). Communities of practice for international students: the role of peer assisted study sessions in supporting transition and learning in higher education. Supplemental Instruction Journal, 1(1), 90-115.

Dearnley, C. McClelland, G., \& Irving, D. (2013). Innovation in teaching and learning in higher education: literature review. Council of deans of health.

Gielen, S., Peeters, E., Duchy, F., Onghema, P., \& Struyven, L. (2010). Improving the effectiveness of peer feedback for learning. Learning and Innovation, 20, 304 315. 
Gwee, M.C.E. (2003). Peer learning: enhancing student learning outcomes. Retrieved from https://nus.edu/2ooi74t.

Hiemstra, R., \& Brockett, G. (1994). Overcoming resistance to self-direction in adult learning. San Franciso: Jossey-Bass

Johnston, J. (2009). How to implement peer learning in your classroom. Research and Resource Guide, 1(7), 1- 4.

Keenan, C. (2014). Mapping student-led peer learning in the UK. York: The Higher Education Academy. Retrieved from http://bit.ly/2oXbnhc.

Keup, J., Rogan, S., \& Kenedy, R. (2015). An international perspective on peer education and leadership best practices in the fye and beyond. Conference presentation.

Knowles, M.S. (1975). Self-directed learning and guide for learner and teachers. Chicago: Follett Publishing.

Knowles, M. (1980). The modern practice of adult education: from pedagogy to andragogy. New York: Cambridge, the Adult Education Company.

Landis, R.B. (2000). Academic success strategies. In Studying Engineering: A Road Map to a Rewarding Career, $2^{\text {nd }}$ ed. Los Angeles: Discovery Press.

Lenning, O., \& Ebbers, L. (1999). The powerful potential of learning communities: improving education for the future. ASHE-ERIC Higher Education Report, 26(6), ERIC Document Reproduction Service No. ED 428606.

Piaget, J. (1972). The psychology of the child. New York: Basic Books.

Shipman, D., \& Hootan, J. (2008). Without enough nurse educators there will be a continual decline in RNs and the quality of nursing care: contending with Faculty shortage. Nurse Education Today, 8(5), 512 - 523.

Stone, R., Cooper, S. \& Cant, R. (2013). The value of peer learning in undergraduate nursing education: a systematic review. ISRN Nursing.

Tinto, V., Russo, P., \& Kadel, S. (1994). Constructing educational communities: increasing retention in challenging circumstances. Community College Journal, 64(4), $26-28$.

Topping, K. J. (2005). Trends in peer learning. Educational Psychology, 25(6), 231645.

Vygotsky, L.S. (1978). Mind in society: the development of higher psychological processes. Cambridge, MA: Harvard University Press.

Williamson, S.N. (2007). The development of self-rating scale of self-directed learning. Nurse Researcher, 14(2), 65-72.

Zaccagnini, M., \& Verenikina, I. (2013). Peer assisted study sessions for postgraduate international students in Australia. Journal of Peer Learning, 6, 86-102.

Zhao, C., \& Kuh, G. D. (2004). Adding value: learning communities and student engagement. Research in Higher Education, 45(2), 115- 138. 
Appendix 1

ID

Date-

\section{Self-Rating Scale for Self-Directed Learning (SRSSDL) Tool}

The aim of this tool is to identify learner's levels of self-directedness in learning in higher education. Please read and encircle the most appropriate response to each statement indicating the level at which you rate yourself. Please note that your first reaction to the statement is the most accurate response; therefore do not spend too long a time on each item.

The "any other" space is provided for you to add any other issues about selfdirectedness in learning you think relevant. A "scoring sheet" is included for you to assess the level of your self-directedness in learning.

\begin{tabular}{|c|c|c|c|c|c|c|}
\hline \multicolumn{7}{|c|}{ Response Key: $5=$ Always $4=$ Often $3=$ Sometimes $2=$ Seldom } \\
\hline 1 & Awareness & \multicolumn{5}{|c|}{ Score } \\
\hline 1.1 & Identify my own learning needs & 5 & 4 & 3 & 2 & 1 \\
\hline 1.2 & I am able to select the best method for my own learning & 5 & 4 & 3 & 2 & 1 \\
\hline 1.3 & $\begin{array}{l}\text { I consider teachers as facilitators of learning rather than } \\
\text { providing information only }\end{array}$ & 5 & 4 & 3 & 2 & 1 \\
\hline 1.4 & I keep up to date on different learning resources available & 5 & 4 & 3 & 2 & 1 \\
\hline 1.5 & I am responsible for my own learning & 5 & 4 & 3 & 2 & 1 \\
\hline 1.6 & I am responsible for identifying my areas of deficit & 5 & 4 & 3 & 2 & 1 \\
\hline 1.7 & I am able to maintain self-motivation & 5 & 4 & 3 & 2 & 1 \\
\hline 1.8 & I am able to plan and set my learning goals & 5 & 4 & 3 & 2 & 1 \\
\hline 1.9 & I have a break during long periods of work & 5 & 4 & 3 & 2 & 1 \\
\hline 1.10 & $\begin{array}{l}\text { I need to keep my learning routine separate from my other } \\
\text { commitments }\end{array}$ & 5 & 4 & 3 & 2 & 1 \\
\hline 1.11 & I relate my experience with new information & 5 & 4 & 3 & 2 & 1 \\
\hline 1.12 & $\begin{array}{l}\text { I feel that I am learning despite not being instructed by a } \\
\text { lecturer }\end{array}$ & 5 & 4 & 3 & 2 & 1 \\
\hline 1.13 & 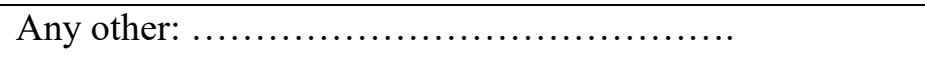 & 5 & 4 & 3 & 2 & 1 \\
\hline 2 & Lear & \multicolumn{5}{|c|}{ Score } \\
\hline 2.1 & I participate in group discussions & 5 & 4 & 3 & 2 & 1 \\
\hline 2.2 & I find peer coaching effective & 5 & 4 & 3 & 2 & 1 \\
\hline 2.3 & I find "role play" is a useful method for complex learning & 5 & 4 & 3 & 2 & 1 \\
\hline 2.4 & $\begin{array}{l}\text { I find inter-active teaching-learning sessions more } \\
\text { effective than just listening to lectures }\end{array}$ & 5 & 4 & 3 & 2 & 1 \\
\hline 2.5 & teaching-learning useful & 5 & 4 & 3 & 2 & 1 \\
\hline 2.6 & I find learning from case studies useful & 5 & 4 & 3 & 2 & 1 \\
\hline 2.7 & $\begin{array}{l}\text { My inner drive directs me towards further development } \\
\text { and improvement in my learning }\end{array}$ & 5 & 4 & 3 & 2 & 1 \\
\hline 2.8 & I regard problems as challenges & 5 & 4 & 3 & 2 & 1 \\
\hline 2.9 & $\begin{array}{l}\text { I arrange my self-learning routine in such a way that it } \\
\text { helps develop a permanent learning culture in my life }\end{array}$ & 5 & 4 & 3 & 2 & 1 \\
\hline
\end{tabular}




\begin{tabular}{|c|c|c|c|c|c|c|}
\hline 2.10 & I find concept mapping is an effective method of learning & 5 & 4 & 3 & 2 & 1 \\
\hline 2.11 & $\begin{array}{l}\text { I find modern educational interactive technology enhances } \\
\text { my learning process }\end{array}$ & 5 & 4 & 3 & 2 & 1 \\
\hline 2.12 & I am able to decide my own learning strategy & 5 & 4 & 3 & 2 & 1 \\
\hline 2.13 & Any other: . & 5 & 4 & 3 & 2 & 1 \\
\hline 3 & Learning Activities & \multicolumn{5}{|c|}{ Score } \\
\hline 3.1 & I rehearse and revise new lessons & 5 & 4 & 3 & 2 & 1 \\
\hline 3.2 & $\begin{array}{l}\text { I identify the important points when reading a chapter or } \\
\text { an article }\end{array}$ & 5 & 4 & 3 & 2 & 1 \\
\hline 3.3 & $\begin{array}{l}\text { I use concept mapping/outlining as a useful method of } \\
\text { comprehending a wide range of information }\end{array}$ & 5 & 4 & 3 & 2 & 1 \\
\hline 3.4 & I am able to use information technology effectively & 5 & 4 & 3 & 2 & 1 \\
\hline 3.5 & $\begin{array}{l}\text { My concentration intensifies and I become more attentive } \\
\text { when I read a complex study content }\end{array}$ & 5 & 4 & 3 & 2 & 1 \\
\hline 3.6 & $\begin{array}{l}\text { I keep annotated notes or a summary of all my ideas, } \\
\text { reflections and new learning }\end{array}$ & 5 & 4 & 3 & 2 & 1 \\
\hline 3.7 & $\begin{array}{l}\text { I enjoy exploring information beyond the prescribed } \\
\text { course objectives }\end{array}$ & 5 & 4 & 3 & 2 & 1 \\
\hline 3.8 & I am able to relate knowledge with practice & 5 & 4 & 3 & 2 & 1 \\
\hline 3.9 & I raise relevant question(s) in teaching-learning sessions & 5 & 4 & 3 & 2 & 1 \\
\hline 3.10 & $\begin{array}{l}\text { I am able to analyse and critically reflect on new ideas, } \\
\text { information or any learning experiences }\end{array}$ & 5 & 4 & 3 & 2 & 1 \\
\hline 3.11 & I keep an open mind to others' point of view & 5 & 4 & 3 & 2 & 1 \\
\hline 3.12 & I prefer to take any break in between any learning task & 5 & 4 & 3 & 2 & 1 \\
\hline 3.13 & Any other: & 5 & 4 & 3 & 2 & 1 \\
\hline 4 & Evaluation & \multicolumn{5}{|c|}{ Score } \\
\hline 4.1 & I self-as & 5 & 4 & 3 & 2 & 1 \\
\hline 4.2 & $\begin{array}{l}\text { I identify the areas for further development in whatever I } \\
\text { have accomplished }\end{array}$ & 5 & 4 & 3 & 2 & 1 \\
\hline 4.3 & I am able to monitor my learning progress & 5 & 4 & 3 & 2 & 1 \\
\hline 4.4 & I am able to identify my areas of strength and weak & 5 & 4 & 3 & 2 & 1 \\
\hline 4.5 & I appreciate when my work can be peer reviewed & 5 & 4 & 3 & 2 & 1 \\
\hline 4.6 & $\begin{array}{l}\text { I find both success and failure inspire me to further } \\
\text { learning }\end{array}$ & 5 & 4 & 3 & 2 & 1 \\
\hline 4.7 & $\begin{array}{l}\text { I value criticism as the basis of bringing improvement to } \\
\text { my learning }\end{array}$ & 5 & 4 & 3 & 2 & 1 \\
\hline 4.8 & I monitor whether I have accomplished my learning goals & 5 & 4 & 3 & 2 & 1 \\
\hline 4.9 & I check my portfolio to review my progress & 5 & 4 & 3 & 2 & 1 \\
\hline 410 & I revi & 5 & 4 & 3 & 2 & 1 \\
\hline 4.11 & I find new learning challenging & 5 & 4 & 3 & 2 & 1 \\
\hline 4.12 & I am inspired by others' success & 5 & 4 & 3 & 2 & 1 \\
\hline 4.13 & Any other: .................. & 5 & 4 & 3 & 2 & 1 \\
\hline 5 & Interpersonal Skills & \multicolumn{5}{|c|}{ Score } \\
\hline 5.1 & $\begin{array}{l}\text { I intend to learn more about other cultures and languages I } \\
\text { am frequently exposed to }\end{array}$ & 5 & 4 & 3 & 2 & 1 \\
\hline 5.2 & I am able to identify my role within a group & 5 & 4 & 3 & 2 & 1 \\
\hline 5.3 & $\begin{array}{l}\text { My interaction with others helps me to develop the insight } \\
\text { to plan for further learning }\end{array}$ & 5 & 4 & 3 & 2 & 1 \\
\hline
\end{tabular}




\begin{tabular}{|c|c|c|c|c|c|c|}
\hline 5.4 & I make use of any opportunities I come across & 5 & 4 & 3 & 2 & 1 \\
\hline 5.5 & I need to share information with others & 5 & 4 & 3 & 2 & 1 \\
\hline 5.6 & I maintain good inter-personal relationships with others & 5 & 4 & 3 & 2 & 1 \\
\hline 5.7 & I find it easy to work in collaboration with others & 5 & 4 & 3 & 2 & 1 \\
\hline 5.8 & communicating verbally & 5 & 4 & 3 & 2 & 1 \\
\hline 5.9 & $\begin{array}{l}\text { I identify the need for inter-disciplinary links for } \\
\text { maintaining social harmony }\end{array}$ & 5 & 4 & 3 & 2 & 1 \\
\hline 5.10 & I am able to express my ideas effectively in writing & 5 & 4 & 3 & 2 & 1 \\
\hline 5.11 & I ams & 5 & 4 & 3 & 2 & 1 \\
\hline 5.12 & $\begin{array}{l}\text { I find it challenging to pursue learning in a culturally } \\
\text { diverse milieu }\end{array}$ & 5 & 4 & 3 & 2 & 1 \\
\hline 5.13 & ................... & 5 & 4 & 3 & 2 & 1 \\
\hline
\end{tabular}

Once you have responded to all the items of the SRSSDL transfer the scores to the correct boxes below and add up your scores as in the following example.

\begin{tabular}{|l|c|c|c|c|c|l|}
\hline Score & 5 & 4 & 3 & 2 & 1 & \\
\hline Items $1.1-1.12$ & 3 & 4 & 3 & 5 & 0 & \\
\hline Total & 15 & 16 & 9 & 10 & 0 & Total Score $=50$ \\
\hline
\end{tabular}

\begin{tabular}{|l|l|l|l|l|l|l|}
\hline Score & 5 & 4 & 3 & 2 & 1 & \\
\hline Items 1.1 - 1.12 & & & & & & \\
\hline Total & & & & & & Total Score $=$ \\
\hline
\end{tabular}

\begin{tabular}{|l|c|c|c|c|c|l|}
\hline Score & 5 & 4 & 3 & 2 & 1 & \\
\hline Items 2.1 - 2.12 & & & & & & \\
\hline Total & & & & & & Total Score $=$ \\
\hline
\end{tabular}

\begin{tabular}{|l|l|l|l|l|l|l|}
\hline Score & 5 & 4 & 3 & 2 & 1 & \\
\hline Items 3.1-3.12 & & & & & & \\
\hline Total & & & & & & Total Score $=$ \\
\hline
\end{tabular}

\begin{tabular}{|l|l|l|l|l|l|l|}
\hline Score & 5 & 4 & 3 & 2 & 1 & \\
\hline Items 4.1-4.12 & & & & & & \\
\hline Total & & & & & & Total Score $=$ \\
\hline
\end{tabular}

\begin{tabular}{|l|l|l|l|l|l|l|}
\hline Score & 5 & 4 & 3 & 2 & 1 & \\
\hline Items 5.1-5.12 & & & & & & \\
\hline Total & & & & & & Total Score $=$ \\
\hline
\end{tabular}

Add all the total scores

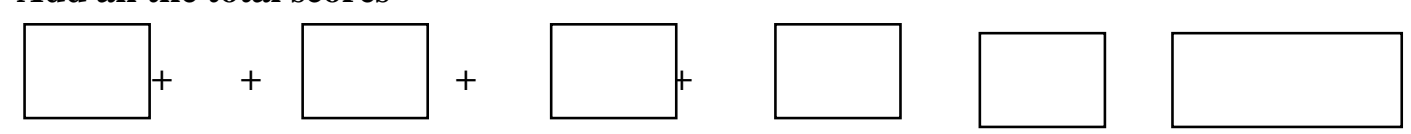


Check the total score with the following scoring range in order to identify your level of self-directedness in learning.

\begin{tabular}{|l|l|l|}
\hline $\begin{array}{c}\text { Scoring } \\
\text { range }\end{array}$ & $\begin{array}{l}\text { Level of Self- } \\
\text { directedness in } \\
\text { learning }\end{array}$ & \multicolumn{1}{|c|}{ Interpretation } \\
\hline $60-140$ & Low & $\begin{array}{l}\text { Guidance is definitely needed from the teacher. Any } \\
\text { specific changes necessary for improvement must be } \\
\text { identified and a possible complete re-structuring of } \\
\text { the methods of learning. }\end{array}$ \\
\hline $141-220$ & Moderate & $\begin{array}{l}\text { This is half way to becoming a self-directed learner. } \\
\text { Areas for improvement must be identified, evaluated } \\
\text { and a strategy adopted with teacher guidance when } \\
\text { necessary. }\end{array}$ \\
\hline $221-$ & High & $\begin{array}{l}\text { This indicates effective self-directed learning. The } \\
\text { goal now is to maintain progress by identifying } \\
\text { strengths and methods for consolidation of the } \\
\text { students' effective self-directed learning. }\end{array}$ \\
\hline 300 & &
\end{tabular}

No matter what your total score, it is essential that you pay particular attention to any individual items of the SRSSDL in which you have scored below 3 as these are the areas in which you may need to improve.

Thank you for completing the questionnaire. 
Appendix 2

Peer Learning Assessment - Self Assessment and Peer Assessment Date................

\begin{tabular}{|c|c|c|c|c|}
\hline Criteria & $\begin{array}{c}4 \\
\text { Very Good }\end{array}$ & $\begin{array}{c}3 \\
\text { Good }\end{array}$ & $\begin{array}{c}2 \\
\text { Satisfactory }\end{array}$ & $\begin{array}{c}1 \\
\text { Not } \\
\text { Satisfactory }\end{array}$ \\
\hline $\begin{array}{l}\text { 1. Learning } \\
\text { goal setting }\end{array}$ & $\begin{array}{l}\text { Participates } \\
\text { actively in } \\
\text { identifying the } \\
\text { SMART learning } \\
\text { goals for the } \\
\text { group }\end{array}$ & $\begin{array}{l}\text { Participates } \\
\text { mostly in } \\
\text { identifying the } \\
\text { SMART } \\
\text { learning goals } \\
\text { for the group }\end{array}$ & $\begin{array}{l}\text { Participates } \\
\text { occasionally in } \\
\text { identifying the } \\
\text { SMART } \\
\text { learning goals }\end{array}$ & $\begin{array}{l}\text { Rarely } \\
\text { participates } \\
\text { in } \\
\text { identifying } \\
\text { the SMART } \\
\text { learning } \\
\text { goals }\end{array}$ \\
\hline $\begin{array}{l}\text { 2. Learning } \\
\text { activities } \\
\text { (themes) }\end{array}$ & $\begin{array}{l}\text { Performs all } \\
\text { learning } \\
\text { activities } \\
\text { interactively and } \\
\text { helps others to } \\
\text { learn }\end{array}$ & $\begin{array}{l}\text { Performs most } \\
\text { learning } \\
\text { activities } \\
\text { interactively } \\
\text { and helps } \\
\text { others to learn }\end{array}$ & $\begin{array}{l}\text { Performs some } \\
\text { learning } \\
\text { activities with } \\
\text { some interaction } \\
\text { with others to } \\
\text { learn }\end{array}$ & $\begin{array}{l}\text { Limited } \\
\text { performance } \\
\text { of learning } \\
\text { activities and } \\
\text { limited } \\
\text { interaction } \\
\text { with others } \\
\text { to learn. }\end{array}$ \\
\hline $\begin{array}{l}\text { 3. Gathering } \\
\text { evidence and } \\
\text { collaboration }\end{array}$ & $\begin{array}{l}\text { Collects a range } \\
\text { of evidence that } \\
\text { relates to the } \\
\text { topic } \\
\text { collaboration } \\
\text { with others. }\end{array}$ & $\begin{array}{l}\text { Collects } \\
\text { evidence which } \\
\text { mostly relates } \\
\text { to the topic in } \\
\text { collaboration } \\
\text { with others. }\end{array}$ & $\begin{array}{l}\text { Collects some } \\
\text { evidence which } \\
\text { relates to the } \\
\text { topic in } \\
\text { collaboration } \\
\text { with others. }\end{array}$ & $\begin{array}{l}\text { Limited } \\
\text { collection of } \\
\text { evidence } \\
\text { which } \\
\text { relates to the } \\
\text { topic. }\end{array}$ \\
\hline $\begin{array}{l}\text { 4. Listening } \\
\text { skills }\end{array}$ & $\begin{array}{l}\text { Listens } \\
\text { attentively to } \\
\text { others' ideas and } \\
\text { provides relevant } \\
\text { feedback }\end{array}$ & $\begin{array}{l}\text { Listens to } \\
\text { others' ideas } \\
\text { mostly and } \\
\text { makes relevant } \\
\text { comments }\end{array}$ & $\begin{array}{l}\text { Sometimes } \\
\text { listens to others' } \\
\text { ideas and makes } \\
\text { some comments }\end{array}$ & $\begin{array}{l}\text { Rarely } \\
\text { listens to } \\
\text { others' ideas } \\
\text { and makes } \\
\text { no } \\
\text { comments } \\
\end{array}$ \\
\hline $\begin{array}{l}\text { 5. Team } \\
\text { work }\end{array}$ & $\begin{array}{l}\text { Cooperates and } \\
\text { agrees fully with } \\
\text { others in team } \\
\text { learning } \\
\text { activities }\end{array}$ & $\begin{array}{l}\text { Cooperates } \\
\text { and agrees } \\
\text { mostly with } \\
\text { others in team } \\
\text { learning } \\
\text { activities }\end{array}$ & $\begin{array}{l}\text { Cooperates and } \\
\text { agrees to some } \\
\text { extent with } \\
\text { others in team } \\
\text { learning } \\
\text { activities }\end{array}$ & $\begin{array}{l}\text { Limited } \\
\text { cooperation } \\
\text { with others } \\
\text { in team } \\
\text { learning } \\
\text { activities }\end{array}$ \\
\hline $\begin{array}{l}\text { 6. Time } \\
\text { Management }\end{array}$ & $\begin{array}{l}\text { Completes all } \\
\text { assigned task on } \\
\text { time }\end{array}$ & $\begin{array}{l}\text { Usually } \\
\text { completes } \\
\text { assigned task } \\
\text { on time without } \\
\text { affecting the } \\
\text { group progress. }\end{array}$ & $\begin{array}{l}\text { Completes some } \\
\text { of the assigned } \\
\text { task just on time }\end{array}$ & $\begin{array}{l}\text { Does not } \\
\text { complete } \\
\text { the assigned } \\
\text { task. }\end{array}$ \\
\hline
\end{tabular}




\begin{tabular}{|c|c|c|c|c|}
\hline $\begin{array}{l}7 . \\
\text { Responsibility }\end{array}$ & $\begin{array}{lr}\text { Performs } & \text { all } \\
\text { assigned } & \text { duties, } \\
\text { helps } & \text { and } \\
\text { supports } & \text { team } \\
\text { members } & \\
\end{array}$ & $\begin{array}{l}\text { Performs most } \\
\text { of the assigned } \\
\text { duties, helps } \\
\text { and supports } \\
\text { team members }\end{array}$ & $\begin{array}{l}\text { Performs some } \\
\text { of the assigned } \\
\text { duties, helps } \\
\text { and supports } \\
\text { team members }\end{array}$ & $\begin{array}{l}\text { Limited } \\
\text { performance } \\
\text { of duties of } \\
\text { assigned } \\
\text { team role }\end{array}$ \\
\hline $\begin{array}{l}\text { 8. Interaction } \\
\text { with team } \\
\text { members }\end{array}$ & $\begin{array}{lr}\text { Interacts } & \text { and } \\
\text { discusses } & \\
\text { relevant points } \\
\text { with all team } \\
\text { members }\end{array}$ & $\begin{array}{l}\text { Interacts and } \\
\text { discusses } \\
\text { relevant points } \\
\text { with most of } \\
\text { the team } \\
\text { members }\end{array}$ & $\begin{array}{l}\text { Interacts and } \\
\text { discusses some } \\
\text { relevant points } \\
\text { with some of } \\
\text { the team } \\
\text { members }\end{array}$ & $\begin{array}{l}\text { Limited } \\
\text { interaction } \\
\text { to discuss } \\
\text { relevant } \\
\text { points with } \\
\text { team } \\
\text { members }\end{array}$ \\
\hline
\end{tabular}

Week

Theme

Write the number of the description (rubrics) above that fits each group members' participation in the proforma below under the collaboration learning skills. Include your team members and your own name in the list.

4 - Very Good: Functioning at a high level within the group and needs to maintain them.

3 - Good: Working well within the group but there is a scope of further improvement in to enhance group work.

2 - Satisfactory: Making an attempt to work effectively but needs some improvement.

1 - Not Satisfactory: Limited attempt to contribute within the group and needs considerable improvement.

Collaborative learning skills:

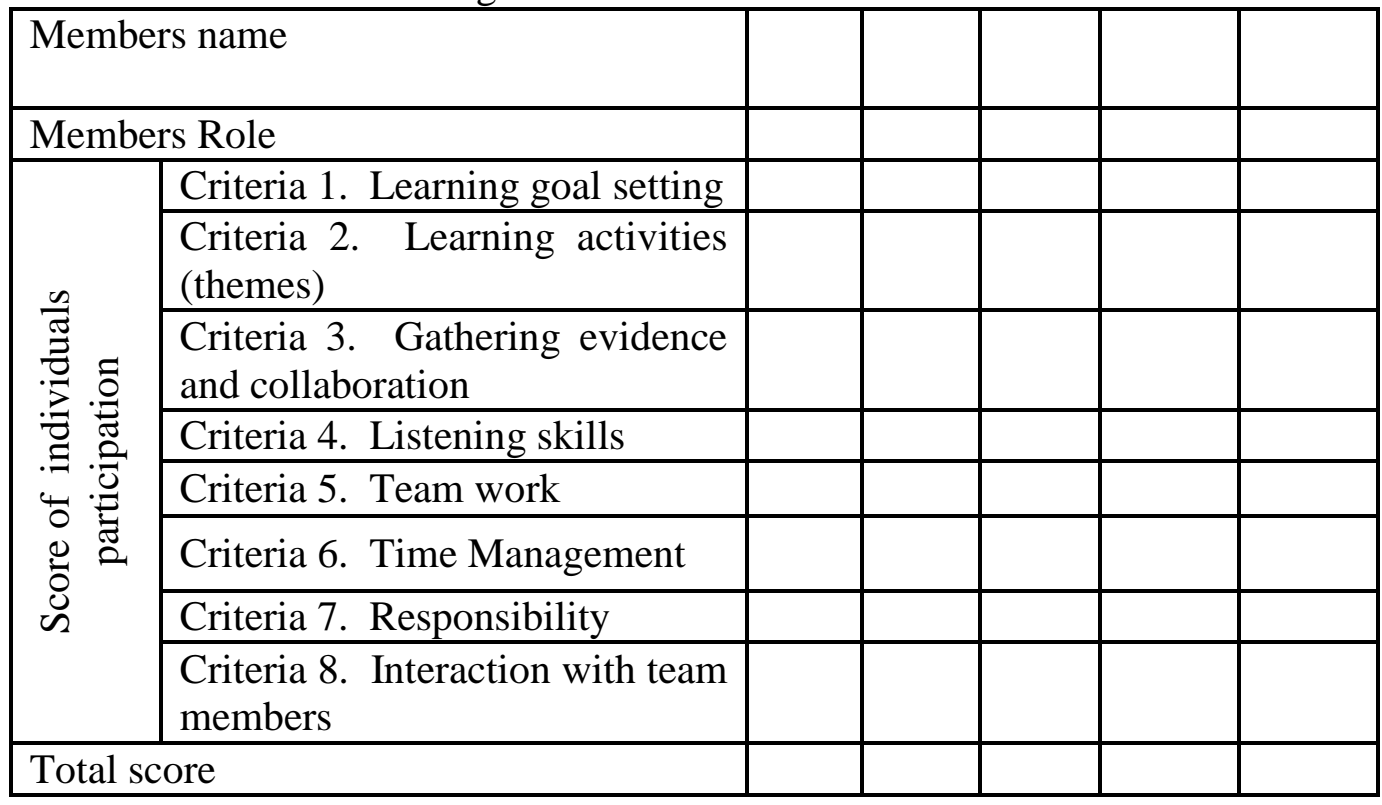


Appendix 3

Group Peer Learning Assessment - Self Assessment and Peer Assessment Date.......... Week ........ Theme...........

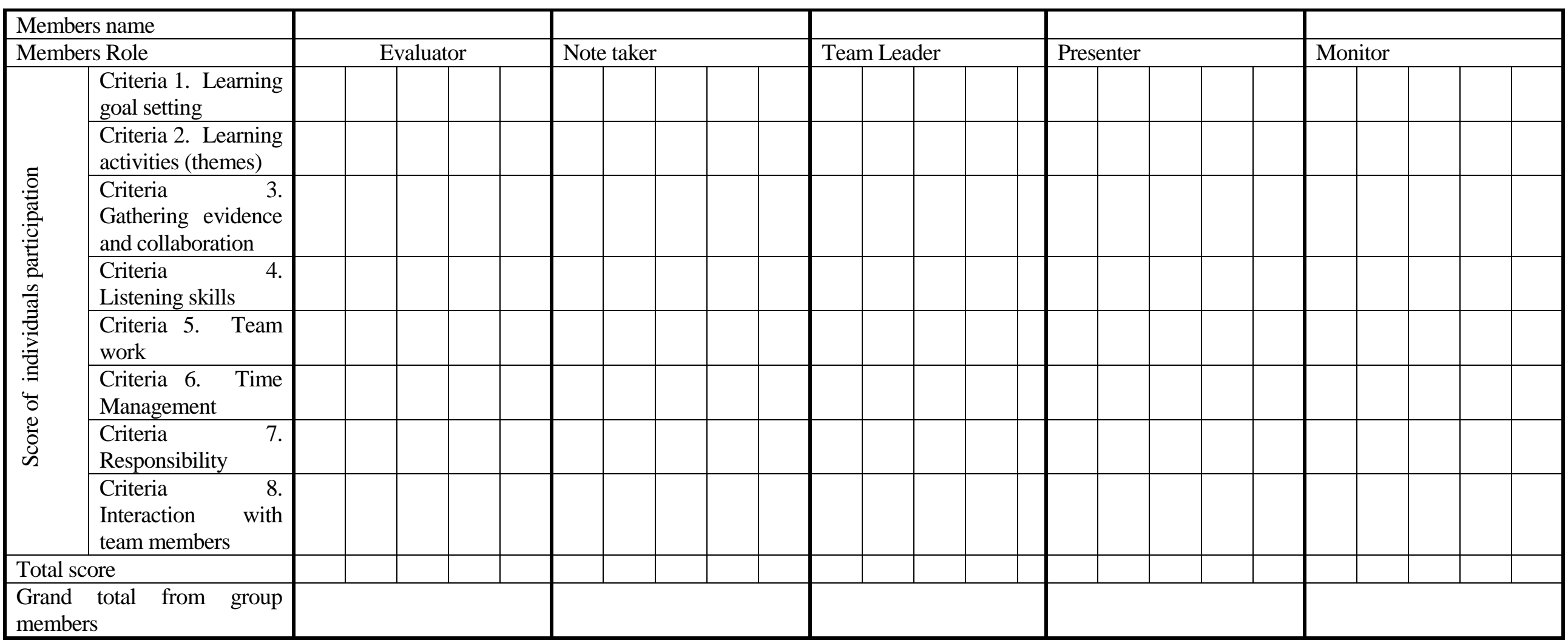


